\title{
The Use of Mobile Technology in Enhancing the Critical Reading Skills of Pre-University ESL Students
}

\author{
Cita Cassiana Henry, Maslawati Mohamad* \\ Faculty of Education, Universiti Kebangsaan Malaysia, Bangi, Malaysia \\ Email: *maslawati@ukm.edu.my
}

How to cite this paper: Henry, C. C., \& Mohamad, M. (2021). The Use of Mobile Technology in Enhancing the Critical Reading Skills of Pre-University ESL Students. Creative Education, 12, 678-695. https://doi.org/10.4236/ce.2021.123047

Received: February 3, 2020

Accepted: March 27, 2021

Published: March 30, 2021

Copyright $\odot 2021$ by author(s) and Scientific Research Publishing Inc. This work is licensed under the Creative Commons Attribution International License (CC BY 4.0).

http://creativecommons.org/licenses/by/4.0/

\begin{abstract}
Critical thinking skills are one of the most soughed after criteria for studies and work in the $21^{\text {st }}$ century, impacted by the industrial revolution that revamped the nature of the job, lifestyle and education. Critical thinking skills develop through the process of critical reading which involves the high order thinking, are lacking among the graduates, contributing to the statistic of unemployment in the nation. The past studies revealed the tertiary students' critical reading skills do not surpass the comprehension level and need for critical reading in English text training. Critical reading skills can be instilled in the tertiary students through continuous practice. In addressing to this problem, a mobile phone application is developed as practising tool, with practice module divided into themes with different levels of difficulties. The purpose of this paper is to meet the need to enhance the critical reading skills of the pre university program students in Samarahan District, Sarawak, Malaysia via purposing the use of ReadMe mobile application as effective language practising tool. The research methodology employed the quantitative approach and data was collected via survey questionnaire with quasi experimental approach involved the administration of pretest, post test and document analysis. It was found that half of the respondents showed improvement in the critical reading competency thus enhanced their interest in reading.
\end{abstract}

\section{Keywords}

Mobile Technology, Critical Reading Skills, English as a Second Language (ESL), Pre-University Students, Mobile Application, Technology and Language Learning

\section{Introduction}

Critical thinking is essential life skills in the $21^{\text {st }}$ century to achieve success at 
work or school (Greiff, Niepel, \& Wüstenberg, 2015) and the deficiency to think critically among fresh graduates (Azmi, Hashim, \& Yusoff, 2018) served as impetus to conduct study on the root of the problem related to the development of critical thinking. Critical thinking is inextricably linked to critical reading because critical thinking occurred if the text is critically understood through critical reading (Kurland, 2000; Handayani, 2018). Thus critical reading skills should be emphasized in the teaching and learning process of reading.

Critical reading skills enable the student to analyze, synthesize and evaluate information in the text and increase the students' capability in expressing their own view and opinions (Norbaiyah, Roose, Farah, \& Juhaida, 2014) and the information comes from variety of sources. The rise of the smart machine, systems and globally connected world with gradual shifting from printed materials to digital materials and demand for digital literacy includes the need to read critically over massive information (Silvhiany, 2019) demand the efficiency used of critical reading skills at tertiary education level and in school. ESL learners with low critical reading skills suffered comprehension exhaustion due to exposure to wide range of unfamiliar vocabulary and information from the use of technology (Norbaiyah et al., 2014) resulting in the learners to consume the information passively (Silvhianny, 2019).

In view of the critical reading level of the nation, critical reading skills are insufficient acquired by the students. Many past studies revealed the tertiary students do not surpass the comprehension level and are lacking critical reading skills (Mohd Zin, Wong, \& Rafik-Galae, 2014; Zainal \& Seng, 2017) and there is need for training to employ the critical reading skills for English text (Sarjit \& Gurnam, 2014). In addition, Programme for International Student Assessment (PISA) 2018 organized by the Organization for Economic Co-operation and Development (OECD) reported the students aged 15 years old in the nation, possessed reading skills below the average standard set by OECD, with diminutive use of critical reading skills (OECD, 2018).

In regards to the critical reading of the tertiary students, it is crucial to address the acquisition of critical reading skills of pre university students who are preparing for admission to degree program in the universities. The inclusion of English language subject at the pre university programme is to prepare the students for the Malaysian University English Test, which is one of the requirements for admission to the degree level. The test emphasized on the reading, writing, listening and speaking skills, and reading has the highest mark weightage. The students in one of the school in the Samarahan District of Sarawak, Malaysia are struggling to surpass the average passing mark, with majority landing in Band 2 for reading test. It is learnt that the students depended on the critical reading practice in the classroom and no responsibility was given to the students to acquire the skills independently resulting in no retention of these cognitive skills for future use. Therefore intervention is required to improve the acquisition of the critical reading skills with integration of mobile technology parallel to 
the style of learning in the $21^{\text {st }}$ century. The aim of this study is to enhance critical reading skills of pre university students in suburban schools in Sarawak, Malaysia via proposing the use of mobile phone application as effective language practicing tool and the research questions are as follow:

1) How does the mobile application improve the pre university ESL learners' critical reading skills?

2) What are the ESL learners' perceptions of the mobile phone application, as critical reading practising tool?

\section{Literature Review}

\subsection{Critical Reading Skills Acquisition}

The acquisition of critical reading skills involved the understanding of critical reading skills, reading strategies and process of acquiring the critical reading skills (Norbaiyah et al., 2014). Critical reading skills are cognitive skills and to acquire these skills, Schunk (2010) posited that the process begins with obtaining the foundation or one piece principle of the knowledge or skills and proceed to the multiple principles or the complexity of the knowledge or skills and mastering through practice or training to achieve efficiency.

Critical reading with success, incurred the use of reading strategies. Hudson (2009) referred reading strategy as any interactive process with the purpose of grasping meaning from the connected text and reading skills function with the setting of such reading strategies. Axelrod and Cooper (1999), highlighted the important critical reading strategies are annotate, preview, contextualize, outline, analyzed option, summarize, paraphrasing, synthesize, questioning and reflecting because as a good reader, these strategies are effective for the reader to evaluate their own practices in the process of developing their own critical reading skills (Hall I. \& Hall D., 2004).

The process of acquiring critical reading skills through practice involves the students using the available critical reading skills in different situation and students plan, monitor and evaluate their own acquisition of the skills parallel to the concept in the meta-cognition of regulation (Flavell, 1979), which involves the meta-cognitive activities that help to control one's thinking on learning using three essential skills. In critical reading, the planning involves setting of goal, and recollection of the function of each critical reading skills which facilitates the choice of strategies needed to read and applying the critical reading skills. The monitoring activity refers to the awareness of comprehension and task performance where students test their own ability on new materials involving continuation of reinforcement, refining, and changing approaches to achieve success in reading. Evaluation entails the whole process by analyzing the mistakes and notion on the success based on the test result.

\subsection{Cognitive Constructivism Theory}

The acquisition of critical reading skills success depends on the construction of 
the knowledge of the skills in the students. The Cognitive Constructivism Theory by Piaget (1976) explained that construction of knowledge occurrs through experience which creates schema that changes, enlarged and made sophisticated through the process of assimilation and accommodation (Padesky, 1994). The assimilation process happens in the construction of knowledge or skills acquired cognitively by experiencing the practices in the constructive environment such as classroom. The application of the assimilated knowledge or skills, proceed with more practices of the knowledge or skills in different situations which puts the learner in the state of equilibrium (Mcleod, 2018). In the state of equilibrium at times, the learner experience disequilibrium and will accommodate to the situation with alternative strategies (Piaget, 1976). This theory is adopted in the Cognitive Constructivist Theory of Multimedia (Bull, 2009) incorporated in the development of the content for the mobile phone application adhere to the specification of interactive digital materials that listed: the content to be context based and accordance to objective of the lesson, encourage active involvement and engagement in learning, digital materials emphasize on students' autonomy development and control over learning and personal growth, and learning outcomes should stimulate a perspective and an understanding.

\subsection{Mobile Technology in Education}

Mobile Assisted Language Learning (MALL) replaced Computer Assisted Language Learning (Chung, Chen, \& Kuo, 2015) due to the evolution of mobile technology proven to ease the deliverance of tasks for language learning and the development of English language from basic features of English instructions such as vocabulary (Wu, 2015), grammar (Ghani, Paris, Shah, Yussof, \& Abbas, 2017) to writing (Kazem, 2015; Morshedi, 2019), listening (Kohzadi, Mohammadi, \& Samadi, 2014) and reading (Hazaea \& Alzubi, 2016) The mobile technologies in the Mobile Assisted Language Learning evolves the rise in the utilization of mobile technologies devices such as mobile phone, PDAs, iPad, MP3 and MP players. Mobile technologies for mobile phone evolved through times with continuous upgrading of features and ability to download many software applications (apps) attributing to meaningful use of this device in all aspects of the life of the users. The apps may be free or incur charges and developed for entertainment, gaming, businesses and education (Gangaiamaran \& Pasupathi, 2017). The advantages of using mobile phone application in improving the ESL learners' reading practice are highlighted in several past studies summaries, as allowing learning at own pace to practise independently with automated feedback (Sarvestani \& Pishkar, 2015; McFadzien, 2015), enabled comprehension of more reading texts (Azli, Shah, \& Mohamad, 2018), improve learners code breaking practices, text participation practice, text using and text analyzing practice (Handayani, 2018) that caused high motivation and interest among the students (Gangaiamaran \& Pasuathi, 2017). 


\subsection{Technology Acceptance Model (TAM)}

The ReadMe is an intervention tool that integrated learning and technology to facilitate students in enhancing their critical reading skills. Since the tool deals with technology, therefore the technology acceptance model (TAM) is adopted in the research. TAM is an information systems theory that models how users come to accept and use the technology. This model introduced by Davis (1989) as in Figure 1, derived from the Theory of Reasoned Action (TRA) (Fishbein \& Ajzen, 1975) pointed that the perception of the user towards the technology will form an attitude towards the technology which influences the behavioral intention that leads to the use of technology as shown in Figure 1. The perception comprises of perception on usefulness (PU), focusing on the degree of usefulness of the technology effortlessly or uncomplicated. External variable refers to social influence on the attitude as everyone is unique. TAM has been applied in numerous studies testing used acceptance of information technology such as for English vocabulary (Chung, Chen, \& Kuo, 2015), blended e-learning technology (Nhu, 2016) and Azli et al. (2018) on reading comprehension.

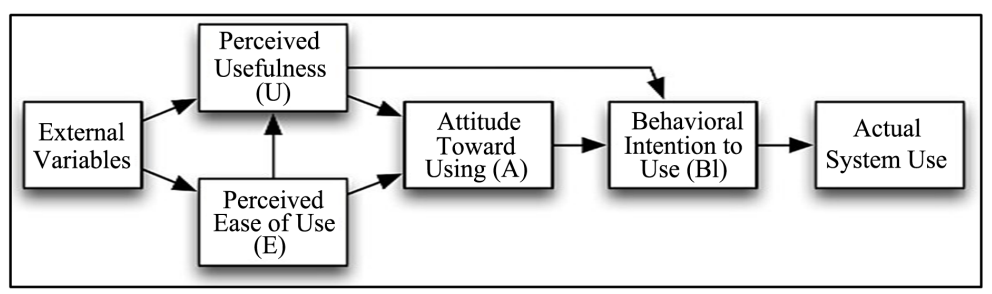

Figure 1. The technology acceptance model, version 1 (Davis, 1989).

\section{Research Methodology}

\subsection{Research Design}

The research employed quantitative research design utilizing quasi-experimental method to test the effect of ReadMe on the students' critical reading performance after the use of ReadMe application as dependent variable and students' performance as independent variable involving the administration of pre test and post test to determine the students' level of critical reading skills. The quantitative survey questionnaire is constructed to collect the respondents' perceptions on the use and usefulness of mobile phone application as practising tool to improve their critical reading skills.

\subsection{Research Population and Sample}

The population for this research estimated a total of 30 pre-university ESL students aged 19 years old from two different classes in the school at the suburban area of Samarahan District in Sarawak, Malaysia. The selection was based on convenient sampling of target group for the research (Dornyei, 2017). The samples are of mix English language proficiency based on their Sijil Pelajaran Malaysia (SPM) examination result as the result affirmed their actual proficiency 
level after 11 years of education. Convenience sampling is used in this study because the researchers intended to learn by discovering, understanding and gain insight focus of a sample (Merriam, 2009), and fulfilling the requirement which the researchers had determined for the study and served the research objectives of this study (Dornyei, 2017).

The demographic profile of the respondents in Table 1 summarized the respondents' proficiency as beginner to intermediate users of English with minimum exposure to English language daily and the lack of interest to read English text.

Table 1. Demographic profile of the respondents.

\begin{tabular}{cccc}
\hline & Demographic Attributes & Frequency & Percentage \\
\hline $\begin{array}{c}\text { Proficiency Level based on } \\
\text { SPM English result }\end{array}$ & $\mathrm{B}$ & 8 & $26.7 \%$ \\
& $\mathrm{C}$ & 8 & $26.7 \%$ \\
Reading English & $\mathrm{D}$ & 6 & $20 \%$ \\
materials everyday & $\mathrm{E}$ & 8 & $26.7 \%$ \\
\hline & Yes & 1 & $3.3 \%$ \\
Source of Exposure & No & 6 & $20 \%$ \\
to English language & Sometimes & 23 & $76.7 \%$ \\
\hline & Mobile/Smart Phone & 19 & $6.7 \%$ \\
& Internet & 7 & $63.3 \%$ \\
\hline
\end{tabular}

*The implication of using the English language proficiency level in SPM is to use the available English language ability to acquire critical reading skills.

\subsection{Research Instruments}

The instruments used in this study are test papers, survey questionnaire and document analysis. The reading test papers for pre test and post test contain 45 questions taken from the past years question papers of MUET which have been used for the MUET examination since 2000 and based on predictive validity study made by Malaysian Examination Council in 2005, on the correlation between MUET and IELTS, and the study made by Rethinasamy and Chuah (2011) that confirmed MUET as valid predicator for measuring the language proficiency of the students. The survey questionnaire constructed to collect data on the perception of the acceptance of the technology, is divided into three parts, measured by four-point Likert-scale range from 1-strongly disagree, 2-disagree, 3 -agree and 4-strongly disagree. The survey questionnaire set for the study is reviewed by experienced lecturers from two higher education institutions to obtain content validity and the reliability of the instruments are built based on Cronbach Alpha value obtained 0.924 above 0.7 indicated the scale are intentionally consistent (Hair, Black, Babin, \& Anderson 2010).

\subsection{Intervention Tool (ReadMe)}

ReadMe application is a tool designed to facilitate critical reading skills practices 
beyond the classroom. The development of the tool utilized MIT application creator in developing Read Me application based on the Cognitive Constructivist Theory of Multimedia (Bull, 2009), that combined the constructivist theory, multiple intelligence theory and cognitive theory of multimedia learning in designing the teacher -made interactive digital materials which specified the content to be context based and accordance to the objective of the lesson, encourage active involvement and engagement in learning, digital materials emphasizing on students' autonomy development and control over learning and personal growth, and learning outcomes should stimulate a perspective and an understanding.

The content of ReadMe as shown in Figure 2 is formatted in the form of thematic practice module specified in the MUET Specification Booklet (MPM, 2015). Reading texts were selected from the past paper examination booklet and workbook, organized according to the needs of the simple to complex questions,

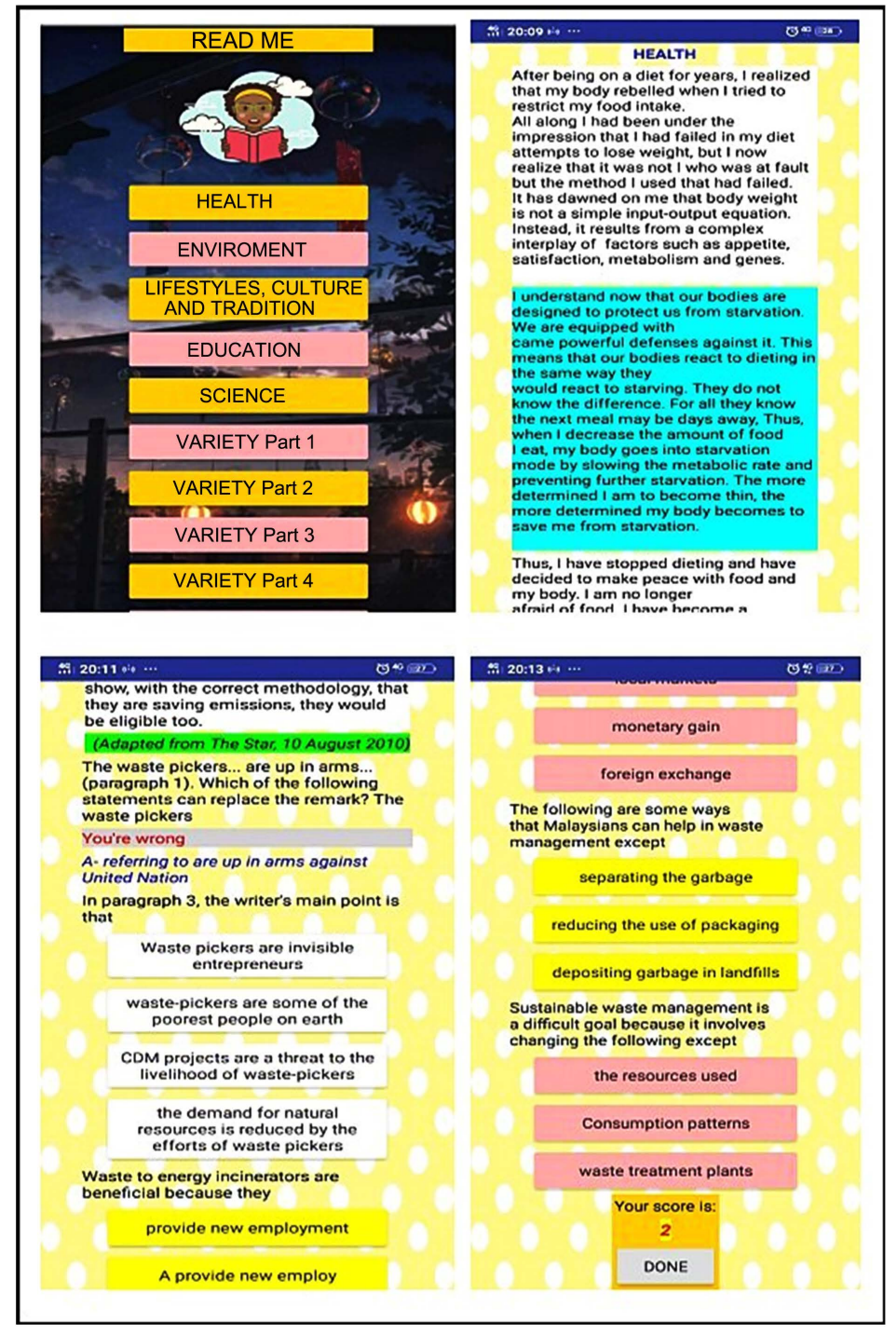

Figure 2. The Content of ReadMe Mobile Application 
in accordance to their arrangement in the MUET reading test paper. ReadMe application features includes the offline mode usage, button for direction of learning process and auto feedback for answer and score for all correct answers.

\subsection{Data Collection Procedure}

The data collection procedure occurred in four phases beginning with the standard procedure of implementing a research study, to the administration of pre-test. The second phase focuses on the revision of critical reading skills and the third phase emphasized on the use of ReadMe application for practice. Administration of post test and collection of respondents' perception of ReadMe application were done online through Google form, were implemented in phase four.

\section{The Findings of the Study}

The aim of this study is to enhance the critical reading skills of the pre university students in Samarahan District via purposing the use of ReadMe apps as effective language practising tool. The findings are divided into two parts. The first part is to answer research question one and the second part is to answer question two on the perception of the respondents towards ReadMe apps.

\subsection{Part One: How Does ReadMe Mobile Phone Application Improve Pre-University ESL Students' Critical Reading Skills?}

In addressing the first research question, pretest and post test were administered to 30 respondents. The result of the two tests have undergone normality test with Mean $>0.05$, revealing that the data, is normally distributed. A descriptive result of the test in Table 2 showed that the post test has a higher performance $($ Mean $=41.43)$ than the pretest $($ Mean $=36.60)$.

Table 2. Descriptive result.

\begin{tabular}{|c|c|c|c|c|c|}
\hline \multicolumn{6}{|c|}{ Paired Samples Statistics } \\
\hline & & Mean & $\mathrm{N}$ & Std. Deviation & Std. Error Mean \\
\hline \multirow{2}{*}{ Pair 1} & Pretest & 36.60 & 30 & 9.790 & 1.787 \\
\hline & Post-test & 41.43 & 30 & 11.110 & 2.028 \\
\hline
\end{tabular}

A parametric test of Paired-Sample T-test was conducted on the data and the result in Table 3 revealed that there is significant difference between pretest and post-test of $\mathrm{t}(29)=-2.966$.

Table 3. Paired samples test.

\begin{tabular}{|c|c|c|c|c|c|c|c|c|c|}
\hline & & \multicolumn{5}{|c|}{ Paired Differences } & \multirow{3}{*}{$\mathrm{t}$} & \multirow{3}{*}{ df } & \multirow{3}{*}{$\begin{array}{c}\text { Sig. } \\
\text { (2-tailed) }\end{array}$} \\
\hline & & \multirow[t]{2}{*}{ Mean } & \multirow[t]{2}{*}{$\begin{array}{c}\text { Std. } \\
\text { Deviation }\end{array}$} & \multirow[t]{2}{*}{$\begin{array}{l}\text { Std. } \\
\text { Error } \\
\text { Mean }\end{array}$} & \multicolumn{2}{|c|}{$\begin{array}{l}\text { 95\% Confidence } \\
\text { Interval of the } \\
\text { Difference }\end{array}$} & & & \\
\hline & & & & & Lower & Upper & & & \\
\hline Pair 1 & Pretest-Post-test & -4.833 & 8.925 & 1.630 & -8.166 & -1.501 & -2.966 & 29 & 0.006 \\
\hline
\end{tabular}


The significant difference in the reading tests score indicates that overall ReadMe, had improved the critical reading skills among the students. However it is insufficient to conclude on the effectiveness of ReadMe solely on the significant difference in mean produced in the paired sample T-test. There are other variables that contributed to the increase in the post test-performance and in this study, which is the respondents' proficiency level. Hence Kruskal-Wallis Test was conducted and the test showed in Table 4 that grade B group had the highest mean (Mean Rank $(M R)=22.31)$, followed by grade $C$ group $(M R=15.39)$, grade $\mathrm{D}$ group $(\mathrm{MR}=10.58)$ and grade $\mathrm{E}$ group $(\mathrm{MR}=12.50)$.

Table 4. Mean rank for group performance.

\begin{tabular}{cccccc}
\hline & Pre Test & & \multicolumn{3}{c}{ Post Test } \\
\hline SPM Grade & N & Mean Rank & SPM Grade & N & Mean Rank \\
\hline B & 8 & 24.94 & B & 8 & 22.31 \\
C & 8 & 13.00 & C & 8 & 15.38 \\
D & 6 & 10.50 & D & 6 & 10.58 \\
E & 8 & 12.31 & E & 8 & 12.50 \\
Total & 30 & & Total & 30 & \\
\hline
\end{tabular}

However the test statistic (Table 5) showed that no significant difference of performance among the group with $\left(\mathrm{x}^{2}(3, \mathrm{~N}=30)=7.656, p>0.5\right)$. This is indicated by the decrease in the performance by grade $B$ group but an increase in performance by grade $\mathrm{C}$ group and slight improvement for $\mathrm{D}$ and $\mathrm{E}$ groups in the post test. Grade B group could be taking the test lightly.

Table 5. Test statistics.

\begin{tabular}{|c|c|c|}
\hline \multicolumn{3}{|c|}{ Test Statistics ${ }^{\mathrm{ab}}$} \\
\hline \multicolumn{2}{|c|}{ Pretest } & Posttest \\
\hline Chi-Square & 12.991 & 7.656 \\
\hline $\mathrm{df}$ & 3 & 3 \\
\hline Asymp. Sig. & 0.005 & 0.054 \\
\hline
\end{tabular}

a. Kruskal Wallis test, b. Grouping variable: SPM grade.

Document analysis is conducted to investigate on the individual performance. Document content the respondents' proficiency level, pretest and psot-test result and the difference between the two results as shown in Table 6 is used in the document analysis and the result revealed that there are improvements in the performance of several individuals for each of the group as showed in Figure 3.

Despite the decrease in mean rank showed in Table 4, in group B, 4 out of 8 respondents shows improvement in their critical reading score and the other half either shows a decrease or remain the same in the pre and post tests. Group C has the highest number of respondents (6 out of 8 ) showing an increase in their 
reading score. The $\mathrm{D}$ group shows 3 out of 5 respondents achieving better score than the E group with only 2 respondents showing progress in their critical reading test. The total number of respondents who have improved in their critical reading skills is 15 respondents, which is half of the total respondents.

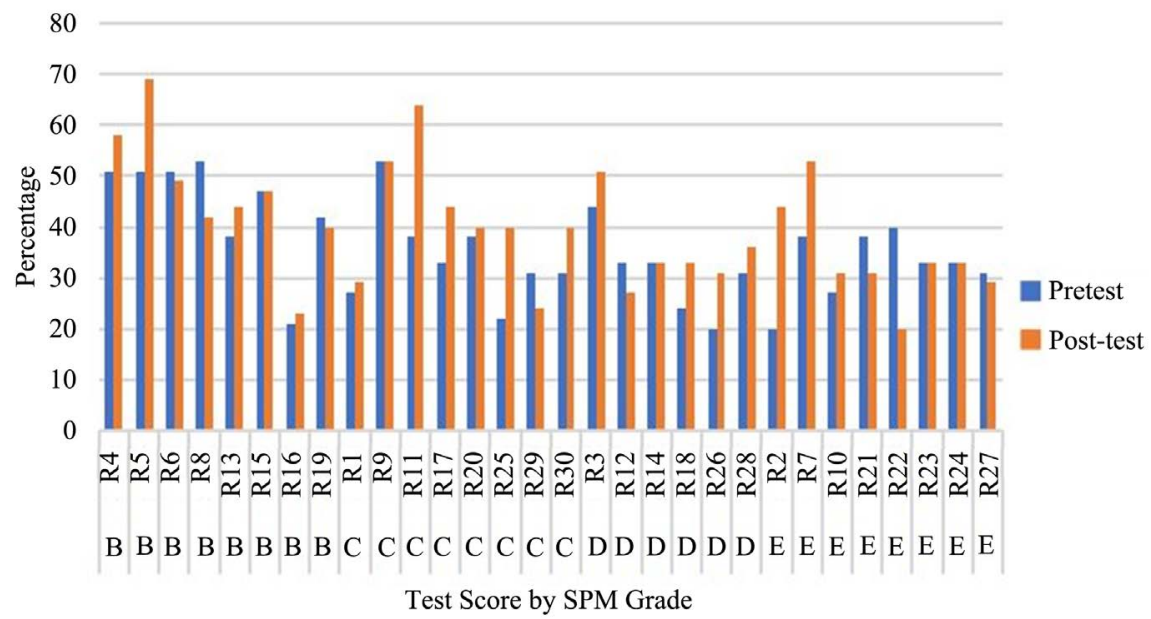

Figure 3. Individual performance in the pretest and post-test.

Table 6. Individual performance in pretest and post-test and the difference.

\begin{tabular}{cccccccccccc}
\hline No & R & G & PT & P-t & D & No & R & G & PT & P-t & D \\
\hline 1 & R4 & B & 51 & 58 & 7 & 17 & R3 & D & 44 & 51 & 7 \\
2 & R5 & B & 51 & 69 & 8 & 18 & R12 & D & 33 & 27 & -6 \\
3 & R6 & B & 51 & 49 & -2 & 19 & R14 & D & 33 & 33 & 0 \\
4 & R8 & B & 53 & 42 & -11 & 20 & R18 & D & 24 & 33 & 9 \\
5 & R13 & B & 38 & 44 & 6 & 21 & R26 & D & 20 & 31 & 11 \\
6 & R15 & B & 47 & 47 & 0 & 22 & R28 & D & 31 & 36 & 5 \\
7 & R16 & B & 21 & 23 & 2 & 23 & R2 & E & 20 & 44 & 24 \\
8 & R19 & B & 42 & 40 & -2 & 24 & R7 & E & 38 & 53 & 15 \\
9 & R1 & C & 27 & 29 & 2 & 25 & R10 & E & 27 & 31 & 4 \\
10 & R9 & C & 53 & 53 & 0 & 26 & R21 & E & 38 & 31 & -7 \\
11 & R11 & C & 38 & 64 & 26 & 27 & R22 & E & 40 & 20 & -20 \\
12 & R17 & C & 33 & 44 & 11 & 28 & R23 & E & 33 & 33 & 0 \\
13 & R20 & C & 38 & 40 & 2 & 29 & R24 & E & 33 & 33 & 0 \\
14 & R25 & C & 22 & 40 & 18 & 30 & R27 & E & 31 & 29 & -2 \\
15 & R29 & C & 31 & 24 & -7 & & & “0” - no change & & \\
\hline 16 & R30 & C & 31 & 40 & 9 & & negative “-” is a decline & \\
\hline
\end{tabular}

Title: $\mathrm{R}=$ Respondents, $\mathrm{G}=$ Grade, $\mathrm{PT}=$ Pretest, $\mathrm{P}-\mathrm{t}=$ Post-test, $\mathrm{D}=$ Difference. Difference: “0" - no change, "-" negative is a decline. 
Random interview via whatsapp was conducted to several respondents of mix proficiency level that showed improvement in score for the post test to find out the learners' experience of using ReadMe. Their experiences are summarized as learning more new vocabularies, read more English text, immediate feedback trigger the learner to analyze their mistake, improve their critical reading skills, develop critical thinking skills and enhance their interest in reading. In addition the respondents related that the use of offline mode is suitable for learning at own pace as it is cost saving and decrease the cost of using prepaid mobile data to access for internet connection and can be used at vicinity with unstable internet connection.

\subsection{Part Two: What are the ESL Learners' Perceptions towards the Mobile Phone Application as Critical Reading Practising Tool?}

To answer this question, a questionnaire consisting of three constructs: useful ness, ease of use and behavior intention was administered online to the respondents in the form of google form. In the section of perception on usefulness of ReadMe, majority of the respondents agreed $(73.4 \%, \mathrm{M}=3.1)$ that ReadMe application has improved their critical reading skills and all of the respondents $(100 \%, M=3.7)$ agreed that ReadMe is useful for practising critical reading. The reason is all of the respondents found that the app provided useful activities $(100 \%, M=3.6)$ and English materials that challenge their critical reading skills $(100 \%, M=3.7)$. Provision on the chance to accomplish more critical reading practice received moderate response of $66.7 \%(\mathrm{M}=2.9)$, however an increase of $93.3 \%(\mathrm{M}=3.4)$ of the respondents agreed that ReadMe made it easier for them to practise critical reading perceived as it had enhanced the effectiveness in using the critical reading skills ( $83.3 \%, M=3.2)$. This is supported by the claim of $90 \%,(M=3.3)$ of the respondents that ReadMe application supported their critical aspect of critical reading. Overall the respondents perceived ReadMe as useful for critical reading practice (Table 7).

The perception of usefulness indicated that ReadMe gained acceptance due the content of the app that provides useful activities to improve critical reading with challenging reading materials.

The second construct for perception of ReadMe application emphasized on the ease of use of the mobile phone application. The analysis (Table 8) revealed that overall, most of the respondents agreed $(96.7 \%, M=3.6)$ that ReadMe is easy to use for practising critical reading skills due to their perception that the activities are interactive $(83.3 \%, \mathrm{M}=3.4)$, allowing them to practise at their own pace ( $100 \%, M=3.4$ ) and providing easy access to their learning materials at any time and place $(93.3 \%, M=3.5)$. In addition, the clear and comprehensible instructions are important to give an overview of the content, received positive response with $96.6 \%(\mathrm{M}=3.5)$ of the respondent agreeing to it. Most of the respondents $(93.3 \%, M=3.3)$ agreed to the use of buttons to ease the flow of the learning process which leads to the point of taking less efforts to be skillful in operating ReadMe apps $(86.6 \%, \mathrm{M}=3.3)$. 
Table 7. Distribution, frequency and means of respondents' perception of usefulness of ReadMe.

\begin{tabular}{|c|c|c|c|c|c|c|}
\hline No & Item & $\begin{array}{l}\text { Strongly } \\
\text { Disagree }\end{array}$ & Disagree & Agree & $\begin{array}{l}\text { Strongly } \\
\text { Agree }\end{array}$ & Mean \\
\hline 1 & $\begin{array}{l}\text { Using ReadMe improve my critical } \\
\text { reading for English text. }\end{array}$ & & $\begin{array}{c}6.7 \% \\
(2)\end{array}$ & $\begin{array}{c}40.7 \% \\
(12)\end{array}$ & $\begin{array}{c}53.3 \% \\
(18)\end{array}$ & 3.1 \\
\hline 2 & $\begin{array}{l}\text { ReadMe is useful for practicing the } \\
\text { critical reading skills. }\end{array}$ & & & $\begin{array}{c}33.3 \% \\
(10)\end{array}$ & $\begin{array}{c}66.7 \% \\
(20)\end{array}$ & 3.7 \\
\hline 3 & $\begin{array}{l}\text { Using ReadMe provides students with } \\
\text { useful activities to improve the critical } \\
\text { reading skills. }\end{array}$ & & & $\begin{array}{c}36.7 \% \\
(11)\end{array}$ & $\begin{array}{c}63.3 \% \\
(19)\end{array}$ & 3.6 \\
\hline 4 & $\begin{array}{l}\text { ReadMe provides English reading } \\
\text { materials that challenge my critical } \\
\text { reading skills . }\end{array}$ & & & $\begin{array}{c}33.3 \% \\
(10)\end{array}$ & $\begin{array}{c}66.7 \% \\
(20)\end{array}$ & 3.7 \\
\hline 5 & $\begin{array}{l}\text { ReadMe made it possible for me to } \\
\text { accomplish more critical reading } \\
\text { practice that would be otherwise be } \\
\text { impossible. }\end{array}$ & $\begin{array}{c}6.7 \% \\
(3)\end{array}$ & $\begin{array}{c}23.3 \% \\
(7)\end{array}$ & $\begin{array}{c}36.7 \% \\
(11)\end{array}$ & $\begin{array}{c}30 \% \\
(9)\end{array}$ & 2.9 \\
\hline 6 & $\begin{array}{l}\text { Using ReadMe makes it easier for me } \\
\text { to practice for critical reading skills. }\end{array}$ & & $\begin{array}{c}6.7 \% \\
(2)\end{array}$ & $\begin{array}{l}50 \% \\
(15)\end{array}$ & $\begin{array}{c}43.3 \% \\
(13)\end{array}$ & 3.4 \\
\hline 7 & $\begin{array}{l}\text { Using ReadMe enhance my effectiveness } \\
\text { in using the critical reading skills. }\end{array}$ & & $\begin{array}{c}13.3 \% \\
(4)\end{array}$ & $\begin{array}{c}53.3 \% \\
(16)\end{array}$ & $\begin{array}{c}33.3 \% \\
(10)\end{array}$ & 3.2 \\
\hline 8 & $\begin{array}{l}\text { ReadMe support critical aspect of my } \\
\text { critical reading practice. }\end{array}$ & & $\begin{array}{l}10 \% \\
(3)\end{array}$ & $\begin{array}{l}50 \% \\
(15)\end{array}$ & $\begin{array}{l}40 \% \\
(12)\end{array}$ & 3.3 \\
\hline 9 & $\begin{array}{l}\text { Overall I find ReadMe useful for my } \\
\text { critical reading practices. }\end{array}$ & & $\begin{array}{l}6.7 \% \\
(2)\end{array}$ & $\begin{array}{c}43.3 \% \\
(13)\end{array}$ & $\begin{array}{l}50 \% \\
(15)\end{array}$ & 3.4 \\
\hline
\end{tabular}

$1=$ Strongly disagree, 2 = Disagree, $3=$ Agree, $4=$ Strongly agree.

Table 8. Distribution, frequency and means of respondents' perception of the ease of use of ReadMe.

\begin{tabular}{|c|c|c|c|c|c|c|}
\hline No & Item & $\begin{array}{l}\text { Strongly } \\
\text { Disagree }\end{array}$ & Disagree & Agree & $\begin{array}{l}\text { Strongly } \\
\text { Agree }\end{array}$ & Mean \\
\hline 1 & I find ReadMe is easy to use. & & $\begin{array}{c}6.7 \% \\
(2)\end{array}$ & $\begin{array}{l}50 \% \\
(15)\end{array}$ & $\begin{array}{c}43.3 \% \\
(13)\end{array}$ & 3.4 \\
\hline 2 & $\begin{array}{l}\text { I find ReadMe practice activities are } \\
\text { interactive. }\end{array}$ & & $\begin{array}{c}6.7 \% \\
(2)\end{array}$ & $\begin{array}{l}50 \% \\
(15)\end{array}$ & $\begin{array}{c}43.3 \% \\
(13)\end{array}$ & 3.4 \\
\hline 3 & $\begin{array}{l}\text { I find ReadMe allows me to practice at } \\
\text { my own pace. }\end{array}$ & & & $\begin{array}{l}60 \% \\
(18)\end{array}$ & $\begin{array}{l}40 \% \\
(12)\end{array}$ & 3.4 \\
\hline 4 & $\begin{array}{l}\text { I find ReadMe allows easy access for } \\
\text { learning materials at any time and place. }\end{array}$ & $\begin{array}{c}3.3 . \% \\
(1)\end{array}$ & $\begin{array}{c}3.3 \% \\
(1)\end{array}$ & $\begin{array}{c}33.3 \% \\
(10)\end{array}$ & $\begin{array}{l}60 \% \\
(18)\end{array}$ & 3.5 \\
\hline 5 & $\begin{array}{l}\text { I find the instruction in ReadMe is clear } \\
\text { and comprehensible. }\end{array}$ & & $\begin{array}{c}3.3 \% \\
(1)\end{array}$ & $\begin{array}{c}43.3 \% \\
(13)\end{array}$ & $\begin{array}{c}53.3 \% \\
(16)\end{array}$ & 3.5 \\
\hline 6 & $\begin{array}{l}\text { I find the used of button in ReadMe } \\
\text { allows easy process of learning. }\end{array}$ & & $\begin{array}{c}6.7 \% \\
(2)\end{array}$ & $\begin{array}{c}53.3 \% \\
(16)\end{array}$ & $\begin{array}{l}40 \% \\
(12)\end{array}$ & 3.3 \\
\hline 7 & $\begin{array}{l}\text { I find it takes less effort to become skillful } \\
\text { of using ReadMe. }\end{array}$ & & $\begin{array}{c}13.3 \% \\
(4)\end{array}$ & $\begin{array}{c}43.3 \% \\
(13)\end{array}$ & $\begin{array}{c}43.3 \% \\
(13)\end{array}$ & 3.3 \\
\hline 8 & Overall I find ReadMe is easy to use. & & $\begin{array}{c}3.3 \% \\
(1)\end{array}$ & $\begin{array}{c}36.7 \% \\
(11)\end{array}$ & $\begin{array}{l}60 \% \\
(18)\end{array}$ & 3.6 \\
\hline
\end{tabular}

1 = Strongly disagree, 2 = Disagree, 3 = Agree, $4=$ Strongly agree . 
The high mean on perception on the ease of use of ReadMe apps indicates that the apps had put the respondents at ease while using the apps, in practising critical reading.

The high mean for perception on the usefulness of ReadMe apps for practising critical reading skills and overall ease of use of the apps, leads to the formation of attitudes and behaviour intention to use mobile applications in assisting language learning. The analysis of the respondents attitude towards ReadMe apps (Table 9), showed positive formation of attitudes towards the use of mobile phone application with majority of the respondents, $(86.7 \%, \mathrm{M}=3.4)$ accepting the mobile phone application as good for practising and this is proven by $876.7 \%$ $(\mathrm{M}=3.4)$ of the respondents showed favour in using ReadMe as critical reading practicing tool. Hence the use of ReadMe apps raised the intention of $66.6 \%$ (M $=3.1$ ) of the respondents to use ReadMe as practising tool for critical reading because the app has enhanced their interest in reading $(73.4 \%, \mathrm{M}=3.2)$.

Table 9. Distribution, frequency and means of respondents' attitude toward ReadMe apps.

\begin{tabular}{|c|c|c|c|c|c|c|}
\hline No & Item & $\begin{array}{l}\text { Strongly } \\
\text { Disagree }\end{array}$ & Disagree & Agree & $\begin{array}{l}\text { Strongly } \\
\text { Agree }\end{array}$ & Mean \\
\hline 1 & $\underline{\text { Attitude }} \underset{\text { Using ReadMe is good for practice }}{ }$ & & $\begin{array}{c}13.3 \% \\
(4)\end{array}$ & $\begin{array}{c}30 \% \\
(9)\end{array}$ & $56.7 \%(17)$ & 3.4 \\
\hline 2 & Using ReadMe is favourable & & $\begin{array}{c}13.3 \% \\
(4)\end{array}$ & $\begin{array}{c}36.7 \% \\
(11)\end{array}$ & $\begin{array}{l}50 \% \\
(15)\end{array}$ & 3.4 \\
\hline 3 & $\begin{array}{l}\text { Intention } \\
\text { I tend to use ReadMe for practicing } \\
\text { critical reading }\end{array}$ & & $\begin{array}{c}43.3 \% \\
(10)\end{array}$ & $\begin{array}{c}23.3 \% \\
\quad(7)\end{array}$ & $\begin{array}{c}43.3 \% \\
(13)\end{array}$ & 3.1 \\
\hline 4 & Using ReadMe enhance my reading interest & & $\begin{array}{c}16.7 \% \\
(5)\end{array}$ & $\begin{array}{c}46.7 \% \\
(14)\end{array}$ & $\begin{array}{c}36.7 \% \\
(11)\end{array}$ & 3.2 \\
\hline
\end{tabular}

1 = Strongly disagree, 2 = Disagree, 3 = Agree, 4 = Strongly agree.

The mobile technology has accelerate the respondents acquisition of the critical reading skills and provide space for personal growth in reading thus form the attitude of favoring the app as good tool for practising critical reading leads to the intention of using the app in the future which correspond with the analysis of attitude and intention in the study by Fishbein and Ajze (1975) that the more favourable a person's attitude towards some object, the more he will perform positive behavior.

\section{Discussion and Conclusion}

\subsection{Effectiveness of the Mobile Phone Application in Improving Critical Reading Skills}

The analysis of pretest and post test signified improvement in the use of critical reading skills among the respondents but the group performance showed no significant difference in mean rank for the test. The document analysis of indi- 
vidual proficiency level with the test results showed unexpected finding that several members of each proficiency groups contributed to the increase in the score of post test indicated that the proficiency level have less impact on the acquisition of critical reading skills but training or practise, determined the success of the acquisition of critical reading skills correlating to the study by Schunk (2010) which explained on the cognitive skills acquisition through practise cause increase in speed and accuracy after learning through multiple principles.

The process of training or practise required the students to set their goal, monitor their acquisition of the critical reading skills through application of the skills to other situation or reading text by continually reinforce, and redefined the use of the critical reading skills. The students' evaluate their learning through the automatic feedback and the score of the practise correlate with the Meta-cognition of Regulation mentioned in the Meta-cognition Theory by Flavell (1979). Through training or practise, students constructed their knowledge and the app is the platform for experiencing the use of the critical reading skills. The students used their available knowledge to analyse, synthesize and evaluate the new information, to arrive to the correct answer. The inclusion of the feature on immediate feedback accelerated the process of learning because the immediate feedback provides students with certainty on the success of certain critical reading skills used to arrive to the answer and to act promptly in correcting the wrong answers, correlating with the study by Sarvestani and Pishkar (2015) and McFadzien (2015) which revealed that auto feedback allows the students to have immediate answer and immediate reaction to assess themselves, making corrections and focus on the mistake, which engaged the students in developing learning skills. This process is parallel to the Cognitive Constructivist Theory by Piaget (1976) which explained that the construction of knowledge is through experience beginning with building the schema which leads to the assimilation and accommodation stage. The accommodation stage enables the students to change strategy to fit into the situation.

The use of the mobile application in assisting the acquisition of the critical reading skills resulted in the enhancement of interest to reading among the respondents. The improvement of the critical reading skills and continuous practise have inculcated the interest to read as the respondents found reading becoming meaningful and the ability to have in depth knowledge of the text. This implies that the students are able to evaluate their own reading practise corresponding to the study made by Hall I. and Hall D. (2004), that a good reader is able to evaluate their own practice in the process of developing their own critical reading skills.

Another finding on the effectiveness of using ReadMe apps for critical reading practice has developed the critical thinking skills of the students as experienced by the R6 respondent. The process of the acquisition of critical reading skills gradually develop critical thinking similar to the study by Kurtland (2000), where students who are able to read critically and understood the text directly, develop their critical thinking. 


\subsection{The Pre-University ESL Students Need for Mobile Phone Application in Assisting Language Learning}

The perception of being a useful mobile phone application derived from the meaningfulness contribution of the mobile phone application in providing knowledge in the learning process. The main idea of developing the apps is to construct the knowledge used for critical reading skills. The findings show high score on the perception on the content of the mobile apps as providing the useful activities and reading text which challenges their critical reading skills. The content of the apps was developed based on the content and practice in the classroom and this correspond to the specification of interactive digital materials in the Cognitive Constructivist Theory of Multimedia by Bull (2009) that the content should be context based and connected to the objective of the lesson or presentation and should make effective use of the students' prior knowledge as explained in the Cognitive Contructivism Theory by Piaget (1976). The content of ReadMe enables the use of critical reading skills from minimum application to maximum use of critical reading skills, supported the students' critical aspect of their reading practise and comprehend more text as found in the study by Azli et al. (2018).

More than half $(60 \%, M=3.6)$ of the respondents strongly agreed on the ease of use of the mobile phone application, indicating the positive acceptance of the use of mobile technology in enhancing the critical reading skills. The high perception was due to the development of the mobile phone application with uncomplicated interface which requires less effort to navigate the apps, corresponding to the definition of the ease of use in the Technology Acceptance Model by Davis (1989) as effortless use of particular system prompt the belief on the ease of use of the system.

Hence the mobile phone application has improved the critical reading skills of the students and gained acceptance from the students with the intention of using the mobile apps in the future.

\section{Conclusion}

This study has contributed to the enhancement of critical reading skills of the pre university ESL students resulting from the use of mobile apps. The use of the app has retained the use of the critical reading skills and indirectly enhanced the interest of reading among the students. In addition, the students received extensive practice of critical reading skills and the use of mobile application supported practising of critical reading beyond the classroom. The study implies that the students are able to learn independently through self discovery. Students may comprehend the knowledge disseminated to them, however providing space for self discovery made the learning process more meaningful. Another implication of this study is, it served as an impetus for teachers to create their own interactive digital materials or mobile apps for teaching and learning to accommodate the learning of the present generation and lead to advantageous use of mobile technology which benefits students' learning. It is time to leverage the use of 
mobile technology in the process of teaching and learning. Therefore the government should emphasize on the use of mobile technology to accommodate learning among the present generation, with provision of technical training on development of mobile apps for the teachers. Limitation of the study includes the aspect of the applications, sample of selected respondents for the research and the duration of the study. The apps designed for this study can only be used on android mobile phone. The spread of Covid-19 pandemic had interrupted the schedule of the implementation period. In term of the sample for the study, the sample is limited to the pre university students of one school in the selected suburban area and the number of the sample is in total of 30 respondents chosen from two different classes. The accuracy depends on the honesty and sincerity of responses to the questionnaire and the use of the apps. Therefore, this study only reflects the situation of the validity of the chosen sample population through convenience sampling and cannot be generalized to the entire population since it is unrepresentative to other setting. However other researchers are recommended to examine the appropriateness of using mobile phone application as practicing tool to assist the students, acquisition of critical reading skills in a larger scale.

\section{Conflicts of Interest}

The authors declare no conflicts of interest regarding the publication of this paper.

\section{References}

Axelrod, R., \& Cooper, C. (1999). A Catolog of Critical Reading Strategies, Reading Critically, Writing Well: A Reader and Guide (5th ed.). New York: Bedford/St. Martin's.

Azli, W. U. A. W., Shah, P. M., \& Mohamad, M., (2018). Perception on the Usage of Mobile Assisted Language Learning (MALL) in English as a Second Language (ESL) Learning among Vocational College Students. Creative Education, 9, 84-98.

Azmi, I. A. G., Hashim, R. C., \& Yusoff, Y. M. (2018). The Employability Skills of Malaysian University Students. International Journal of Modern Trends in Social Sciences, 1, $1-14$.

Bull, P. H. (2009). Cognitive Constructivist Theory of Multimedia Design: A Theoretical Analysis of Instructional Design for Multimedia Learning. In EdMedia+ Innovate Learning (pp. 735-740). Chesapeake, VA: Association for the Advancement of Computing in Education (AACE). http://www.editlib.org/p/31581

Chung, H.-H., Chen, S.-C., \& Kuo, M.-H. (2015). A Study of EFL College Students' Acceptance of Mobile Learning. Procedia-Social and Behavioral Sciences, 176, 333-339. https://doi.org/10.1016/j.sbspro.2015.01.479

Davis, F. D. (1989). Perceived Usefulness, Perceived Ease of Use, and User Acceptance of Information Technology. MIS Quarterly, 13, 319-340. https://doi.org/10.2307/249008

Dornyei, Z. (2007). Research Methods in Applied Linguistics. Oxford: Oxford University Press.

Fishbein, M., \& Ajzen, I. (1975). Belief, Attitude, Intention and Behaviour: An Introduction to Theory and Research (p. 290). Reading, MA: Addison-Wesley. https://people.umass.edu/aizen/f\&a1975.html 
Flavell, J. H. (1979). Metacognition and Cognitive Monitoring: A New Area of Cognitive-Developmental Inquiry. American Psychologist, 34, 906-911. https://doi.org/10.1037/0003-066X.34.10.906

Gangaiamaran, R., \& Pasupathi, M. (2017). Review on Use of Mobile Apps for Language Learning. International Journal of Applied Engineering Research, 12, 11242-11251.

Ghani, R. A., Paris, T. N. S. T., Shah, M. I. A., Yussof, R. L., \& Abas, H. (2017). Mobile Assisted Language Learning (MALL) in Developing Second Language Learners' Understanding of Grammar. Journal of Academia UiTM Negeri Sembilan, 5, 187-208.

Greiff, S., Niepel, C., \& Wüstenberg, S. (2015). 21st Century Skills: International Advancements and Recent Developments. Thinking Skills and Creativity, 18, 1-3. https://doi.org/10.1016/j.tsc.2015.04.007

Hair, J. F., Black, W. C., Babin, B. J., \& Anderson, R. E. (2010). Multivariate Data Analysis (7th ed.). Upper Saddle River, NJ: Prentice Hall.

Hall, I., \& Hall, D. (2004). Evaluation and Social Research: Introducing Small-Scale Practice. https://doi.org/10.1007/978-1-349-91681-8 https://www.researchgate.net/publication/321877093 Evaluation and Social Research Introducing_Small-Scale Practice

Handayani, R. (2018). Employing Critical Reading Strategy to Promote Students' High Order Thinking Skills. Pancaran Pendidikan, 7, 51-56. https://doi.org/10.25037/pancaran.v7i2.174

Hazaea, A. N., \& Alzubi, A. A. (2016). The Effectiveness of Using Mobile on EFL Learners' Reading Practices in Najran University. English Language Teaching, 9, 8-21. https://doi.org/10.5539/elt.v9n5p8

Hudson, T. (2009). Teaching Second Language Reading. ELT Journal, 63, 89-91. https://doi.org/10.1093/elt/ccn061

Kazem, N. (2015). The Effect of Mobile-Assisted Language Learning (MALL) on Guided Writing Skill of Iranian Upper-Intermediate EFL Learners. Journal of Applied Linguistic and Language Research, 2, Corpus ID: 5517085.

Kohzadi, H., Mohammadi, F. A., \& Samadi, F. (2014). Is There a Relationship between Critical Thinking and Critical Reading of Literary Texts: A Case Study at Arak University (Iran). International Letters of Social and Humanistic Sciences, 33, 63-76. https://doi.org/10.18052/www.scipress.com/ILSHS.33.63

Kurtland, D. (2000). Ciritcal Reading, at Its Core, Plain and Simple. http://www.criticalreading.com/critical reading core.htm

McFadzien, N. (2015). Why Is Effective Feedback so Critical in Teaching and Learning? Journal of Initial Teaching Inquiry, 1, 16-18. https://pdfs.semanticscholar.org/989f/ad2627f5f7b0269c5db249baa96b5bd5e8ef.pdf

McLeod, S. (2018). Piaget's Theory and Stages of Cognitive Development. Developmental Psychology, Simply Psychology.

Merriam, S. B. (2009). Qualitative Research: A Guide to Design and Implementation. Revised and Expanded from Qualitative Research \& Case Study Applications in Education (p. 79). San Francisco, CA: Jossey-Bass.

Mohd Zin, Z., Wong, B. E., \& Rafik-Galea, S. (2014). Critical Reading Ability and its Relation to L2 Proficiency of Malaysia ESL Learners. The Southeast Asian Journal of English Language Studies, 20, 43-54. https://doi.org/10.17576/3L-2014-2002-04

Morshedi, T. A. (2019). Effects of Mobile Assited Language Learning (MALL) on Speaking Proficiency (A Case of Learn Daily Mobile App). Reads Conference: 2nd International Conference on Advances Research in Humanities and Arts, Milan, 30 October-1 
November 2019, 136.

MPM (2015). MUET Specification and MUET Handbook. Kuala Lumpur: Malaysian Examination Council.

https://umexpert.um.edu.my/public view.php?type=publication\&row=NjQzNDc\%3D

Nhu, K. T. N. (2016). The Adoption of Blended E-Learning Technology in Vietnam using Revision of the Technology Acceptance Model. Journal of Information Education: Research, 15, 253-282. https://doi.org/10.28945/3522

Norbaiyah, A. K. Roose, N. S., Farah, H. A. J., \& Juhaida I. (2014). The Importance of Teaching Critical Reading Skills in a Malaysian Reading Classroom. The 2014 WEL International Academic Conference Proceedings, Bali Indonesia, 18-21 My 2014, 208219.

OECD, (2018). PISA Report 2018. https://www..oecd.org/pisa/publications/pi.

Padesky, C. A. (1994). Schema Changes Process in Cognitive Therapy. Clinical Psychology and Psychotherapy, 1, 267-278. https://doi.org/10.1002/cpp.5640010502

Piaget, J. (1976). Cognitive Development in Children: Piaget Development and Learning. Journal of Research in Science Teaching, 2, 176-186. https://doi.org/10.1002/tea.3660020306

Rethinasamy, S., \& Chuah, K.-M. (2011). The Malaysian University English Test (MUET) and Its Use for Placement Purposes: A Predictive Validity Study. Electronic Journal of Foreign Language Teaching, 8, 234-245. https://doi.org/10.2139/ssrn.2146007

Sarjit, K. S., \& Gurnam, K. S. (2014). Evaluating the Critical Literacy Practices of Tertiary Students. Procedia-Social and Behavioral Sciences, 123, 44-52. https://doi.org/10.1016/j.sbspro.2014.01.1396

Sarvestani, M. S., \& Pishkar, K. (2015). The Effect of Written Corrective Feedback on Writing Accuracy of Intermediate Learners. Theory and Practice in Language Studies, 5, 2046-2052. https://doi.org/10.17507/tpls.0510.10

Schunk, D. H. (2010). Learning Theories: An Educational Perspective (6th ed., pp. 129130). Boston, MA: Pearson Education. (Publishing as Allyn\&Bacon)

Silvhiany, S. (2019). Critical Digital Literacies in Education 4.0: Preapring Students for Uncertainties of Post-Truth World. Lingua, Journal of Bahasa \& Sastra, 19, 102.

Wu, Q. (2015). Designing a Smartphone App to Teach English (L2) Vocabulary. Computers Education, 85, 170-179. https://doi.org/10.1016/j.compedu.2015.02.013

Zainal, Z., \& Seng, N. M. (2017). Critical Reading Skills at Tertiary Level. LSP International Journal, 4, 117-130. https://doi.org/10.11113/lspi.v4n1.50 